\title{
The Future of Corporate Financing in Europe
}

\author{
Rüdiger Fahlenbrach • Dirk Hackbarth · Jörg Rocholl ${ }^{1}$ Erik Theissen • \\ Marliese Uhrig-Homburg
}

Corporate financing is an important prerequisite for companies to invest and grow. This holds in particular for European companies in the aftermath of the global financial crisis and the subsequent sovereign debt crisis in several European countries, from which not all companies and economies have yet fully recovered. While other economies have traditionally relied on financing through markets, Europe has been characterized by the predominance of bank lending over other forms of financing.

Looking ahead, European companies face an increasing number of challenges and opportunities in their access to finance. First, the recent crisis continues to play a significant role for the future of corporate financing in Europe. Banks across the continent have been severely hit by the crisis and forced to deleverage their balance sheets, thus imposing challenges for the availability of credit to their corporate and retail clients. Regulators and policy-makers have reacted to the financial crisis by increasing capital and liquidity requirements in banking regulation, triggering a discussion on whether and how the increased requirements affect corporate access to bank lending.

Second, the European Union has initiated the Capital Markets Union in an attempt to strengthen market-based financing and thus to reduce the dependence on bank financing in Europe. While the concrete actions are in the process of being determined and prepared to be implemented, important aspects comprise the exact design of European debt and equity capital markets, the challenge of providing sufficient access to the financing of small and medium-sized enterprises (SMEs), and the need to provide startup financing for young and innovative companies.

J. Rocholl

Joerg.Rocholl@esmt.org

1 ESMT, Berlin, Germany 
Third, recent advances in digitalization and access to data have facilitated the creation of new financing means such as peer-to-peer lending and crowdfunding. These forms of financing may seem to be at odds with existing theoretical considerations on the need for financial intermediation in overcoming information asymmetry by screening and monitoring. But they already represent significant (and significantly growing) markets. Furthermore, they may raise new questions regarding the need for investor protection and its exact design, issues currently being analyzed by academics and regulators alike.

Against this background, the current Special Issue "The Future of Corporate Financing in Europe" comprises four papers which address the question of how the future of corporate financing in Europe will shape.

Jiménez, Ongena, Peydró, and Saurina analyze the short-term and long-term effects of monetary policy on bank credit risk-taking. They use a comprehensive credit register from Spain and show that lower short-term interest rates prior to loan origination induce banks to soften their lending standards and grant loans with a higher default probability. At the same time, conditional on a loan being granted, lower interest rates reduce the default probability of loans, probably due to the lower refinancing costs. In sum, lower interest rates have a completely different impact on new versus existing loans.

Feihle and Lawrenz investigate the German market for bonds to small and medium-sized enterprises (SMEs), so-called Mittelstandsanleihen. While this market started with a significant issuing activity shortly after the financial crisis, it came almost to a standstill in 2014. The paper shows that issuers in this market segment experience a decline in net income as well as operating performance after the issuance in comparison to non-issuers, which are matched by a propensity score matching process.

Lohmann and Ohliger analyze nonlinear relationships and their effect on corporate defaults. In particular, they test in a generalized additive model the impact of performance indicators from corporate financial statements on the likelihood of bankruptcy. The authors find for German companies that statistically and economically relevant nonlinear relationships based on a company's adjusted equity ratio, asset structure ratio based on tangible assets, adjusted return on assets, sales, and age have predictive power for a company's likelihood of bankruptcy.

Schumacher and Paul take a closer view at the Capital Market Union (CMU), launched by the European Commission with the goal of improving the access to corporate financing in Europe. The main goal of the CMU is to broaden the financing vehicles for European companies and reduce the strong reliance on bank debt. The authors consider the consistency and desirability of the objectives attached to the CMU, the need for market interventions, and its effectiveness and efficiency. They provide mixed findings and conclude that the overall benefits of the CMU remain to be seen.

Rüdiger Fahlenbrach, Dirk Hackbarth, Jörg Rocholl, Erik Theissen, Marliese UhrigHomburg

(Special Issue Editors) 